\title{
Does time of protective procedure and genotype of chamomile affect yield?
}

\author{
JOLANTA KOWALSKA ${ }^{1 *}$, KATARZYNA SEIDLER-ŁOŻYKOWSKA², MAGDALENA \\ JAKUBOWSKA ${ }^{3}$, DARIUSZ DROŻDŻYŃSKI ${ }^{4}$
}

\author{
${ }^{1}$ Department of Biological Pest Control and Organic Agriculture \\ Institute of Plant Protection - NRI \\ Węgorka 20 \\ 60-318 Poznań, Poland \\ ${ }^{2}$ Department of Botany, Breeding and Agricultural Technology of Medicinal Plants \\ Institute of Natural Fibres and Medicinal Plants \\ Kolejowa 2, 62-064 Poznań, Poland \\ ${ }^{3}$ Department of Monitoring and Signalling of Agrophages \\ Institute of Plant Protection - NRI \\ Węgorka 20, \\ 60-318 Poznań, Poland \\ ${ }^{4}$ Department of Pesticide Residue Research \\ Institute of Plant Protection - NRI \\ Węgorka 20 \\ 60-318 Poznań, Poland \\ *corresponding author: phone: +48 61 8649077, e-mail: j.kowalska@iorpib.poznan.pl
}

\section{Summary}

Objective: Chamomile plants (Chamomilla recutita L. Rausch) are often attacked by pests, which usually cause the decrease of raw material yield and its quality. The objects of field trial were two chamomile cultivars: Złoty Łan $(4 n)$ and Promyk $(2 n)$ cultivated under organic regime. The aim of this study was to evaluate of impact of the spinosad treatment and its time of application on two chamomile cultivars: cv. Promyk $-2 n$ and $\mathrm{cv}$. Złoty Łan $-4 n$ exposed to insect pests.

Methods: The first treatment with spinosad as a preventative control (P) was performed in the early phase of plant development (seven leaves). Intervention (I) treatment was made in green bud phase. In both terms of observation insect pests were observed and collected. In each spraying application of $0.06 \mathrm{~g}$ of spinosad 
per 1 liter of water was used.

Results: Spinosad was able to limit the number of pest population and finally increased yielding of the treated cultivars as compared to the untreated plants. Time of spinosad application for cv. Złoty Łan plants was not statistically siginificant, although was more effective for the preventative treatment of cv. Promyk in the increasing of the plant biomass $\left(283.8 \mathrm{~g} \cdot \mathrm{m}^{-2}\right)$ and seed $\left(32 \mathrm{~g} \cdot \mathrm{m}^{-2}\right)$ yields than intervention.

Conclusion: Protection treatment with spinosad might be recommended in chamomile cultivation and it is more effective than intervention in diploid cultivar which begin blooming earlier than tetraploid. Essential oil content was not related with protection treatment for diploid cultivar, although intervention in tetraploid cultivar caused higher content of oil.

Key words: essential oil, chamomile, organic farming, control of insect pests, spinosad

Słowa kluczowe: olejek eteryczny, rumianek, rolnictwo ekologiczne, zwalczanie szkodników upraw, spinosad

\section{INTRODUCTION}

Many species of medicinal and aromatic plants are cultivated for industrial purposes. Cultivation of plant material should meet regional and national safety requirements [1]. Organic agriculture is a production system that sustains the health of soil, ecosystems and people, therefore, only selected substances of the Commission Regulation (EC) 889/2008 are allowed [2]. Chamomile (Matricaria recutita L. (Asterales: Asteraceae)) is one of the oldest and best defined medicinal plants which is frequently grown for the production of flower heads. During herb cultivation, pests could cause the reduction of the flower head yield and often contaminate them that droppings and dead larvae. Diseases might affects the content of biologically active substances and increase the microbiological contamination [3].

In Poland, chamomile tetraploid cultivar Złoty Łan is common. This cultivar is characterized by higher yields of flower heads, essential oil and flavonoids due to its greater inflorescence weight and thousand seed weight, as compared to diploid ones [4]. The content of essential oil changes in various development stages: content in seven leaves and green bud phase differ from di- and tetraploid cultivars $[5,6]$ depending on three groups of factors: genotype, environmental conditions and agrotechnical factors [7].

The main problem of medicinal plants cultivation is the lack of protection recommendations and products registered for these crops. Insecticides are not allowed in organic cultivation in Poland [8]. Several problems of medicinal plant protection against pests could be solved using the natural insecticide - spinosad, that is approved for organic farming $[9,10]$. Spinosad is metabolic product of a soil-dwelling bacterium [11]. Spinosad is highly effective against many insect species and has a short residual period [12]. It acts as a stomach and contact poison and degrades rapidly in the environment [13], its toxicity to birds and mammals is also low. Its safety for some beneficial insects also has been reported by Kowalska and Kühne [14]. Effects of this active substance occur in several minutes after treatment, in some cases resulting in death of the pest after several hours.

The aim of the study was to evaluate the most effective time for using different protection strategies of insects control with spinosad in two cultivars (genotypes) of chamomile exposed to insect pests. The working hypothesis assumed that different genotypes of chamomile have impact on the occurrence of insect pests and this fact determines the appropriate time of insecticide application. Protection treatment in appropriate phenophase of different genotypes of chamomile might influence the yield of the chamomile flower head and essential oil content.

\section{MATERIAL AND METHODS}

The experiment was carried out on a organic field certified by accredited body experimental in 20172018, near Poznań, Poland (N52 $21^{\prime}$ E16 ${ }^{\circ} 48^{\prime}$ ). The experiments were set up in a randomized complete block design in three replicates. In each year of experiment in April, seeds of two chamomile cultivars (own production) were sown directly on the plots. Each plot had $8.1 \mathrm{~m}^{2}$. The objects of field trial were two chamomile cultivars Złoty Łan (4n) and Promyk (2n). The first treatment with spinosad as a preventative control $(\mathrm{P})$ was performed in the early phase of plant development (seven leaves). Intervention (I) treatment was made in green bud phase. In both terms of observation insect pests were observed and collected. In each spraying, 
application $0.5 \mathrm{ml}$ of Biospin $120 \mathrm{SCl}^{-1}$ water $(0.06 \mathrm{~g}$ active substance) was used. All treatments were performed with use of hand sprayer "Kwazar". Untreated plants were sprayed with water only in this same volume as the treated plot. During the experiment flying insect pests were monitored using yellow traps with water placed on end of May, every year. One yellow trap was set in each replicate. Insect pests picked from the yellow trap were systematically exchanged for new ones, segregated and identified into species or families; the quantitative analysis was performed. Insect pests were removed after 7 days from traps directly before each treatment. At full flowering stage raw material (flower heads) was randomly collected, from $1 \mathrm{~m}^{2}$ selected random area of each plot. The flower heads were air-dried in a shaded and well ventilated place for 2 weeks. The seeds were randomly collected from $1 \mathrm{~m}^{2}$ area of each plot. The following parameters were determined: yield of fresh and dried flower heads, seed yield and essential oil content. The essential oil was hydro-distillated from chamomile flowerheads, following the methods recommended by European Pharmacopoeia, 2008 [15].

Obtained results were analyzed by analysis of variance (one way ANOVA) and the differences between means were verified with the Tukey range test at the significance level of $p<0.05$. The calculations were performed for each cultivar separately.

Ethical approval: The conducted research is not related to either human or animal use.

\section{RESULTS AND DISCUSSION}

The greatest problem in cultivation of herbal plants is the protection of crops against pests. Harmful organisms cause significant yield losses and reduce the commercial value of the collected raw material. The average yield losses that occur when the insecticide and fungicides are discontinued are estimated at $30-40 \%$ [16]. In our experiments, cultivated chamomile was infested by four groups of insect pests occurring in different numbers in relation to different stages of development (tab. 1).

Both years, in the first half of June, mainly winged black bean aphid Aphis fabae Scop. (Hemiptera: Aphididae), common pollen beetle Meligethes aeneus Fab. (Coleoptera: Nitidulidae) and some species from the Curculionidae family, Thysanoptera and other species were noted.

Preventive treatment $(\mathrm{P})$ coincided with the early development phase of plants - seven leaves. Table 1 showes the occurrence of pests in this stage (means in one trap were 21 and 24 insects in cv. Złoty Łan and cv. Promyk, respectively). Higher number of caught insects was recorded for diploid cultivar Promyk -24 and 16/trap, on average, for seven leaves and green bud stage of development, respectively (tab. 1). It is confirmed in practice that diploid plants earlier (from 4 to 7 days) reach that development stage than tetraploid plants and those starting their blooming. That is why more developed plants are more frequently occupied by insects that cause damage to plants. During visual monitoring of experimental plants the first flying $\mathrm{A}$. $\mathrm{fa}$ bae individuals were observed just on diploid plants.

The highest values of fresh and dried flower heads and yield of seeds were obtained for cv. Promyk only after preventative treatment are presented in table 2 .

This suggests that the early application of spinosad was effective for diploid cultivar and the number of insect pests decreased. Early treatment was

Table 1.

Mean number of collected insect pests in yellow traps during the field experiments related to stage of chamomile plant and genotype of plantss

\begin{tabular}{|c|c|c|c|c|c|c|c|c|c|c|c|c|}
\hline \multirow{3}{*}{$\begin{array}{l}\text { Collected insect } \\
\text { pests }\end{array}$} & \multicolumn{6}{|c|}{ cv. Promyk (2n) } & \multicolumn{6}{|c|}{ cv. Złoty Łan $(4 n)$} \\
\hline & \multicolumn{3}{|c|}{ Seven leaves phase } & \multicolumn{3}{|c|}{ Green bud phase } & \multicolumn{3}{|c|}{ Seven leaves phase } & \multicolumn{3}{|c|}{ Green bud phase } \\
\hline & $\begin{array}{l}\text { trap } \\
\text { No. } 1\end{array}$ & $\begin{array}{l}\text { trap } \\
\text { No. } 2\end{array}$ & $\begin{array}{l}\text { trap } \\
\text { No. } 3\end{array}$ & $\begin{array}{l}\text { trap } \\
\text { No. } 1\end{array}$ & $\begin{array}{l}\text { trap } \\
\text { No. } 2\end{array}$ & $\begin{array}{l}\text { trap } \\
\text { No. } 3\end{array}$ & $\begin{array}{l}\text { trap } \\
\text { No. } 1\end{array}$ & $\begin{array}{l}\text { trap } \\
\text { No. } 2\end{array}$ & $\begin{array}{l}\text { trap } \\
\text { No. } 3\end{array}$ & $\begin{array}{l}\text { trap } \\
\text { No. } 1\end{array}$ & $\begin{array}{l}\text { trap } \\
\text { No. } 2\end{array}$ & $\begin{array}{l}\text { trap } \\
\text { No. } 3\end{array}$ \\
\hline Aphis fabae & 5 & 5 & 1 & 1 & 2 & 1 & 3 & 0 & 3 & 0 & 0 & 0 \\
\hline Curculionidae & 2 & 0 & 1 & 3 & 3 & 0 & 3 & 1 & 2 & 2 & 1 & 0 \\
\hline Meligethes aeneus & 1 & 1 & 1 & 0 & 1 & 1 & 1 & 1 & 1 & 0 & 0 & 0 \\
\hline Thysanoptera & 3 & 3 & 1 & 2 & 1 & 1 & 3 & 2 & 1 & 6 & 0 & 1 \\
\hline Total number & \multicolumn{3}{|c|}{24} & \multicolumn{3}{|c|}{16} & \multicolumn{3}{|c|}{21} & \multicolumn{3}{|c|}{10} \\
\hline
\end{tabular}


Table 2.

Mean values (2017-2018) of chamomile yield related to cultivars (genotypes) and treatment with spinosad

\begin{tabular}{|c|c|c|c|c|}
\hline $\begin{array}{c}\text { Combination of protection } \\
\text { strategy }\end{array}$ & $\begin{array}{c}\text { Fresh flower } \\
\text { head yield }\left[\mathrm{g} / \mathrm{m}^{2}\right]\end{array}$ & $\begin{array}{l}\text { Dried flower head yield } \\
\qquad\left[\mathrm{g} / \mathrm{m}^{2}\right]\end{array}$ & $\begin{array}{l}\text { Seed yield } \\
{\left[\mathrm{g} / \mathrm{m}^{2}\right]}\end{array}$ & Essential oil content [\%] \\
\hline \multicolumn{5}{|c|}{ cv. Złoty Łan (4n) } \\
\hline $\begin{array}{c}\text { Prevention } \\
\text { (1 treatment at seven leaves phase) }\end{array}$ & $367.4 \mathrm{~ns}$ & $77.4 \mathrm{~ns}$ & $43.4 \mathrm{~ns}$ & $0.65 \mathrm{ab}$ \\
\hline $\begin{array}{c}\text { Intervention (1 treatment at green } \\
\text { bud phase) }\end{array}$ & $338.3 \mathrm{~ns}$ & $70.5 \mathrm{~ns}$ & $42.9 \mathrm{~ns}$ & $0.85 \mathrm{~b}$ \\
\hline Untreated plants & $335.7 \mathrm{~ns}$ & $77.8 \mathrm{~ns}$ & $34.5 \mathrm{~ns}$ & $0.5 \mathrm{a}$ \\
\hline \multicolumn{5}{|c|}{ cv. Promyk $(2 n)$} \\
\hline $\begin{array}{c}\text { Prevention } \\
\text { (1 treatment at seven leaves phase) }\end{array}$ & $283.8 \mathrm{~b}$ & $68.3 \mathrm{~b}$ & $32 \mathrm{~b}$ & $0.8 \mathrm{~ns}$ \\
\hline $\begin{array}{l}\text { Intervention (1 treatment at } \\
\text { green bud phase) }\end{array}$ & $228.4 \mathrm{a}$ & $53.3 \mathrm{a}$ & $25.2 \mathrm{a}$ & $0.7 \mathrm{~ns}$ \\
\hline Untreated plants & $223.8 \mathrm{a}$ & $54.4 \mathrm{a}$ & $28.2 \mathrm{ab}$ & $0.7 \mathrm{~ns}$ \\
\hline
\end{tabular}

ns - non statistical important differences, analysis was made for each cultivar separately, $p<0.05$

$\mathrm{a}, \mathrm{b}$ - values followed by the same letter are not statistically different at $p<0.05$

performed when initial insect pests were detectable on the plants, monitoring of yellow traps allowed to confirm their presence and treatment with spinosad limited damage to young plants. It is concluded that early (preventive) treatment contributed to significant higher yield as compared to intervention treated and untreated plants only for cv. Promyk (mean $283.8 \mathrm{~g} \cdot \mathrm{m}^{-2}$ of flower heads, 228.4 and 223.8 , respectively), although the yield of cv. Złoty Łan was higher. It was not related to protection treatment, but to genotype (tab. 2).

Later treatment (intervention) made at stage of green bud did not protect plants against damage by insect pests. Statistical analysis showed significant differences in yield, depending on the time of spinosad application only in diploid (cv. Promyk). Seed yield was also the highest (mean $32 \mathrm{~g} \cdot \mathrm{m}^{-2}$ ) after preventive treatment of cv. Promyk. Differences in seed yield between untreated and intervention treatment were not significant for diploid plants. Treatment as intervention has negative impact on seed yield for cv. Promyk while for cv. Złoty Łan it was not significant.

The highest content of essential oil was recorded in flower heads of cv. Złoty Łan after intervention treatment (mean 0.85 and $0.65 \%$ for intervention and preventive treatment, respectively), while there were no significant differences in essential oil content of cv. Promyk flower heads. It is known that chamomile tetraploid cultivar Złoty Łan is characterized by greater inflorescence weight and greater 1000 seeds weight, higher yields of flowerheads, essential oil and flavonoids, as compared to diploid ones [17].

In the literature on medicine plants agrotechnical recommendations can be found, while there are no studies on non-chemical crop protection. In Poland, there are no insecticides authorized for use in medicinal crops. Spinosad only is an insecticide approved to be used in organic farming. Evaluation of its insecticidal potential in chamomile cultivation is possible. Obtained results allow to state that spinosad applied at seven leaves phase was the most effective in decreasing the number of insects in diploid cv. Promyk.

Different genotypes used in field experiments demonstrated a varied morphological structure of plants, different occupation of plants by pests and different effects of foliar treatments applied against insects. This was confirmed by Woropaj-Janczak et al, [18] in their study on the effect of biostimulant foliar application in different genotypes. Their results showed that phenolic compounds increased in herb yield, but only in tetraploid plants, however diploid plants bloomed more abundantly and contained more essential oil in flower heads. Our results showed that essential oil content in diploid plants was not related with spinosad treatment, regardless of time of application and stage of plant development. Nevertheless, essential oil content in flower heads of cv. Złoty tan was significantly higher in treated plants, especially after intervention $(0.85 \%)$. For diploid plants no differences were noted. It allows to state that tetraploid cultivar is more sensitive for such agrotechnical 
measurements than foliar treatment. The results obtained should be confirmed in other tests that would allow to establish practical guidelines.

\section{CONCLUSIONS}

Our study suggests that a single application of spinosad can protect young plants of chamomile at the stage of seven leaves development. Diploid plants are earlier occupied by insects than tetraploid plants. Treatment with spinosad can be recommended for protection of diploid cultivar and contribute to higher yield in organic farming systems. The essential oil content in the diploid cultivar was not affected by pest control treatment, however in tetraploid plants the highest content of oil was noted.

Conflict of interest: Authors declare no conflict of interest.

\section{REFERENCES}

1. Lubbeab A, Verpoorte R. Cultivation of medicinal and aromatic plants for specialty industrial materials. Industr Crops Prod 2011; 34(1):785-801. doi: http://dx.doi.org/10.1016/j. indcrop.2011.01.019

2. Commission Regulation (EC) No. 889/2008 of 5 September 2008 laying down detailed rules for the implementation of Council Regulation (EC) No 834/2007 on organic production and labelling of organic products with regard to organic production, labelling and control.

3. Kosalec I, Cvek J, Tomić S. Contaminants of medicinal herbs and herbal products. Arch Industr Hyg Toxicol 2009; 60(4):485-501. doi: http:// dx.doi.org/10.2478/10004-1254-60-2009-2005

4. Seidler-Łożykowska K. Effect of the selected weather conditions on essential oil, $\alpha$-bisabolol and chamazulene content in flower heads of chamomile (Chamomilla recutita (L.) Rausch.). J Ess Oil Res 2010; 22 (1): 45-48.

5. Letchamo W. Developmental and seasonal variations in flavonoids of diploid and tetraploid chamomile ligulate florets. J Plant Physiol 1996; 148(6):645-651. doi: http://dx.doi.org/10.1016/ S0176-1617(96)80361-0
6. Šalamon I. Effect on the internal and external factors on yield and qualitative and quantitative characteristics of chamomile essential oil. ISHS Acta Hort 2007; 749:45-64. doi: http://dx.doi. org/10.17660/ActaHortic.2007.749.3

7. Otto LG, Junghanns WR, Plescher A, Sonnenschein M, Sharbel TF. Towards breeding of triploid chamomile (Matricaria recutita L.) - ploidy variation within German chamomile of various origin. Plant Breeding 2015; 134 (4):485-493.

8. Kowalska J, Remlein-Starosta D, SeidlerŁożykowska K, Bocianowski J. Influence of Trichoderma asperellum [T1] on growth of lemon balm (Melissa officinalis L.) in different system of cultivation. Acta Sci Polon Hort Cult 2014; 13(1):91-102.

9. Daglish GJ, Nayak MK, Byrne VS. Is there a role for spinosad in protecting Australian grain from insect. In: Proc Austr Post Harvest Tech Conf 2003:78-81.

10. Kühne S, Reelfs T, Ellmer F, Moll E, Kleinhenz B, Gemmer C. Efficacy of biological insecticides to control the Colorado potato beetle (Leptinotarsa decemlineata) in organic farming. In: Proc of $2^{\text {nd }}$ Sci Conf Isofar and $16^{\text {th }}$ IFOAM Congress 2008; 1:480-483.

11. Thompson GD, Dutton R, Sparks TC. Spinosad - a case study: an example from a natural products discovery programme. Pest Manag Sci 2000; 56:696-702. doi: http://dx.doi. org/10.1002/1526-4998(200008)56:8<696::AidPs182>3.0.Co;2-5

12. Salgado VL. Studies on the mode of action of spinosad: insect symptoms and physiological correlates. Pest Biochem Physiol 1998; 60(20):91102.

13. Cisneros J, Goulson D, Derwent LC, Penagos DI, Hernandez O, Williams T. Toxic effects of spinosad on predatory insects. Biol Contr 2002; 23(2):156-163. doi: http://dx.doi.org/10.1006/ Pest.1998.2332

14. Kowalska J, Kühne S. Effect of biological plant protection products on beneficial insects in organic potatoes crops. J Res Appl Agr Eng 2010; 55(3):191-194. 
15. European Pharmacopoeia, $6^{\text {th }}$ Council Of Europe, Strasbourg 2008; 1:680-682.

16. Seidler-Łożykowska K, Kucharski W, Mordalski R. Ekologiczna uprawa roślin zielarskich. Radom 2005.

17. Seidler-Łożykowska K. Odmiany rumianku pospolitego (Chamomilla recutita (L.) Rausch.) o podwyższonej zawartości alfa-bisabololu jako źródło surowca wysokiej jakości. Herba Pol 2003; 3/4:323-324.

18. Woropaj-Janczak M, Andrzejewska J, Skinder Z. Reaction of German chamomile (Chamomilla recutita L. Rausch.) cultivars to biostimulants and foliar fertilisation. Herba Pol 2011; 57(1):16-26. 